\title{
Diversity and abundance of macrofungi in rubber agroforests in southwestern Nigeria
}

\author{
O. O. Osemwegie and J. A. Okhuoya
}

O. O. Osemwegie (omorefo@yahoo.com) and A. J. Okhuoya, Dept of Plant Biology and Biotechnology, Univ. of Benin, PMB 1154, Benin City, Edo State, Nigeria.

\begin{abstract}
The mushroom diversity was studied for 14 months in Edo State, southwestern Nigeria. A total of 76 macrofungi tantamount to 333 fruit bodies were encountered, $74 \%$ of which were identified and named. The basidiomycetes and members of the family Tricholomataceae were the best represented taxa while species on wood-based substrates made up $66 \%$ of the total mushroom taxa. The monthly mushroom abundance profile, diversity and species richness for each sampled plot correlated with local meteorological factors, age of the sampled sites and distribution of wood-based substrates. Jaccard, Sorensen and Bray-Curtis similarity index values showed that plots A and D, representing young actively managed and old abandoned rubber tree plantations, respectively, were the most dissimilar in mushroom composition. The hypersensitive response of macrofungal fruit bodies to climate variables qualify mushrooms as veritable biomonitors or bioindicators of climate change. This study supported earlier reports that rubber agroforests are a depauperate pool of utilitarian mushrooms.
\end{abstract}

Biodiversity studies on mushrooms across the globe have been biased towards agroecosystems and have been focused on forests that cover $30 \%$ of the Earth's land surface (FAO 2006). To fulfil the food needs of the global populace there has been a systematic replacement of natural forests with agroforests. Agroforests have been recognised as a good alternative reservoir of macrofungi (Treu 1998, Flynn et al. 2009, Osemwegie and Okhuoya 2009). However, the impact of mushroom diversity, composition and functional group diversity on ground and above-ground forest and agroforest ecosystem processes is not yet fully understood. There is, however, a great volume of knowledge on the effects of loss or addition of functional groups of higher plants and animals on ecosystem functions (Tilman et al. 1997). The influence of tree diversity, and associated physical and chemical constituents, in various types of forests on mushroom fructification, composition, abundance and species richness has been studied by Shigeki et al. (1994), Lindblad (2001), Jumpponen et al. (2004), and Laitung and Chauvet (2005). Osono (2007) worked on the mechanistic role of mushrooms in forest litter decomposition, while Lindner et al. (2006) reported the implications of changes in diversity and species composition of mushrooms with wood-inhabiting traits on the biodiversity, health and productivity of forest ecosystems. These studies have stressed the significance of macrofungi in nature conservation planning and forestry management contrary to agroecosystems (Straatsma et al. 2001).

Agroforests, although a veritable and popular contributor to national revenue, covers a large area of southern
Nigeria but are seldom mentioned in the world's mushroom pool lists. There are only a few reports on the collection of edible, medicinal mushrooms, and other mushrooms of unprecedented utilitarian values to humans (Osemwegie and Okhuoya 2009). This is contrary to reports that linked agriculture to the current decline in species diversity of plants and animals across the globe (Osemwegie et al. 2006, Flynn et al. 2009). Studies comparing the biodiversity of macrofungi in agroforests and matured secondary forest in Nigeria are few. A recent study by Osemwegie et al. (2010) showed that the natural forests harbours more mushroom diversity, have higher species abundance, richness and number of unshared (endemic) species compared to agroforests (monoculture tree stands). The effect of indiscriminate picking of naturally growing mushrooms for diverse use in Nigeria on the delivery of ecosystem functions, structure of mushroom assemblage, speciation and rate of species loss have not yet been studied. Elaborate and long-term studies of mushroom ecology in agroecosystems is required to fully understand their systematic and mechanistic contributions to the ecosystem's health and productivity. The level of influence of environmental factors on the occurrence and behaviour of fruit bodies which partially represent fungi living in varied substrates remains understudied compared to their forest counterparts (Vogt et al. 1992, Straatsma et al. 2001, Munguia et al. 2006).

This study is in accordance with growing global interest at describing, estimating and understanding biotic diversity, especially at the local and regional ecosystem levels, for 
effective sustainable utilization and planning for biodiversity conservation. It aims at identifying the macrofungi associated with rubber agroforests in Edo State, Nigeria. It also seeks to understand the impact of environmental factors (temperature, humidity, wind speed and rainfall) on fruit body occurrence, behaviour and/or macrofungal community structure vis-a-vis litterfall dynamics.

\section{Material and methods}

The study was carried out at the Rubber Research Inst. of Nigeria (RRIN) located in Iyanomo, Ikpoba-Okha Local Government Area of Edo State, approximately $29 \mathrm{~km}$ from Benin City $\left(6^{\circ} 00^{\prime}-6^{\circ} 15^{\prime} \mathrm{E}, 5^{\circ} 30^{\prime}-5^{\circ} 45^{\prime} \mathrm{N}, 27 \mathrm{~m}\right.$ a.s.l. $)$. The area covers about 2078 hectares $\left(20.78 \mathrm{~km}^{2}\right)$ comprising secondary forest and about $4 \mathrm{~km}^{2}$ of various clones/varieties of rubber trees. The climate of the study area is characterised by two discernable seasons: the wet season (Apr-Oct) and the dry season (Nov-Mar). The study area lies within the heavy rainfall zone with an average annual rainfall of between 2000-2450 mm (annual rainfall range 1230-2580) which peaks in Jun and Sep, respectively. Temperature is highest $\left(29-36^{\circ} \mathrm{C}\right)$ in Nov-Apr and lowest $\left(20-21^{\circ} \mathrm{C}\right)$ from Jun-Oct. The topography of the study area is slightly undulating and transversed by a valley of a semi-permanently dried-up stream, where the vegetation is of the typical secondary rainforest type. The area has sandy and loamy clay soils with a $\mathrm{pH}$ range of 4.9-6.1, and very limited amount of minerals. Various geologic rocks comprising migmatite (gneisses complex), metaigneous rocks, charnockitic rocks, older granites and unmetamorphosed dolerite dyke were recorded by Rahman (1976) in the study area.

\section{Studied plantations}

The study was carried out in 4 randomly selected rubber plantations each measuring about 1 ha and belonging to separate age groups i.e. two 30-35 years old plots (A and B), and 2 older plots (50-55 years) (C and D). The study sites were linked by a stretch of road, unequal distance apart $(\geq 5 \mathrm{~km}$ ), and was each characterised by mixed or multicloned rubber trees. Plots A and B contained 6-8 m tall rubber trees that were actively tapped for latex and weeded once a year. Plots $\mathrm{C}$ and $\mathrm{D}$ were abandoned plantations with taller trees, not less than $7.5 \mathrm{~m}$ tall and with thick undergrowth. The plots were each tagged (permanent) with coloured ribbons (red, yellow, blue) as permanent plots of $50 \times 50 \mathrm{~m}$, all about $6 \mathrm{~m}$ away from the agroforest edge (road). The tagged plots were randomly surveyed for $3 \mathrm{~h}$ twice a month for macrofungi using various foray materials such as hand trowel, pen knife, small paint brush for removing loose sand particles, cane basket and a battery powered high resolution digital camera. Extra trained hands (labour) were also employed in the survey to ensure a more robust capture of mushroom taxa. Collections and preservation of macrofungi were carried out according to Lodge et al. (2004). Preliminary identification of some of the observed species was based on macroscopic features using a variety of primary literature such as field monographs, books of coloured mushrooms (Largent and Their 1984, Largent 1986, Arora 1991, Lincoff 2005) and the internet. Species requiring further identification were assigned collection numbers (RRIN01, RRIN02 etc.) and tagged as unidentified. Important information such as habit, habitat, colour, smell (if any), phenology (period of fruit body appearance) and type of substrate were noted in the field and also used for identification. The study was carried out for a period of 14 months, spanning over two seasons. Mushrooms collected during the study were oven dried overnight at $65-68^{\circ} \mathrm{C}$ in a continuous air circulation chamber (Lodge et al. 2004, Mueller et al. 2004), bagged in Ziploc bags and kept in the Mushroom Biology Unit, Dept of Plant Biology and Biotechnology, Univ. of Benin.

\section{Ecological parameters}

Daily record of rainfall, wind speed, relative humidity and temperature of the study area were supplied by the Meteorological Dept of the Rubber Research Inst. of Nigeria. Mushroom abundance (measure of the total number of mushrooms) was determined by a manual count of macrofungi and/or their fruit bodies over a mapped area. A group/patch of fruitbodies was counted as one macrofungus.

\section{Litterfall study}

Litterfall from each plot was collected using 8 wooden litter trays measuring $1 \times 1 \times 0.1 \mathrm{~m}$ with a $0.5 \mathrm{~mm}$ wire mesh floor. The litter trays were raised $10.5 \mathrm{~cm}$ above ground level, placed randomly in the mapped plot and their position was changed monthly. The monthly litterfall within each litter tray, from each mapped plot were collected in labelled polyethylene bag, air dried for at least $8 \mathrm{~h}$, oven dried to constant weight, and weighed using a top-loaded digital equipment.

\section{Statistical analysis of ecological parameters and litterfall}

The abundance data obtained during the study were analysed using EstmateS (Colwell 2005) for species richness, and biodiversity indexes. The species accumulation curve for the study areas was plotted and species similarity (shared species) indexes computed according to Colwell and Coddington (1994). Litter mass was statistically analysed using SPSS 15.

\section{Results}

A total of 76 morphologically different species of mushrooms belonging to Ascomycetes and Basidiomycetes were found during the 14 month study period. In total, 333 widely varied fruit bodies belonging to agaric, polypore, 
cup, club and tuberous forms were found. The average number of fruit bodies per species per month was 333/76 = 4.38. Of these, $73.7 \%$ belonging to 25 different families, have been identified and named. The families Tricholomataceae, Polyporaceae, Coprinaceae with 9, 8 and 5 species, respectively, and the Coprinus, Ganoderma, Pleurotus and Xylaria genera were the best represented taxa (Table 1). The rubber plantations varied in both species composition and number, with plots $\mathrm{B}$ and $\mathrm{D}$ having a higher number of identified species (35 and 37 species, respectively) while plot A had the highest number (9) of unidentified (whose identity requires further verification by expert taxonomist) species. Plot $\mathrm{D}$ had the highest number of unique (unshared) species (Table 2). The fruit bodies of Auricularia auricular Judae (Bull.) Quél., Coprinus acuminatus (Romagn.) P. D. Orton, Cyathus striatus (Huds.) Willd., Daldinia concentrica (Bolt.) Ces \& De Not., Nothopanus sp., Pleurotus squarrosulus (Fr.) Kumm. and Schizophyllum commune Fr. were consistent throughout the study period, gregarious or caespitose and ranked amongst the most abundant (dominant) recorded taxa (Table 1). Woody substrates supported mushroom growth more than the decomposing litter substrate. Nineteen percent of the total mushrooms recorded exhibited facultative substrate colonization properties or colonized more than one type of substrate (Fig. 1).

\section{Abundance, species richness, diversity and similarity indexes}

Abundance (number of fruit bodies) was higher (88 fruit bodies) in plot B compared to the other plots (Table 2). Species richness indices such as Chao 1 and Jackknife showed that plot D had the highest species richness, while the lowest values were obtained for plot A (Table 3). The measure of species rarity or species with total abundance value of 1 was estimated by the Singleton index(number of species with only one individual) and the highest value was recorded for plot C. Biodiversity estimators such as Fisher's Alpha and Simpson indices showed a progressive trend along age gradient from plots $\mathrm{A}-\mathrm{D}$, with plot $\mathrm{D}$ showing the highest biodiversity. This also reflected the total number of individuals (Table 3).

The species-sample based accumulation curve which assesses inventory completeness did not plateau or reached an asymptote. In addition, the observed lack of overlap by the curves reflects a significant difference in the number of species recorded per sampled plot (Fig. 2).

The mushroom compositional similarities or distinctiveness between the various sampled plots were estimated using the Jaccard, Soresen, Morisita-Horn and Bray-Curtis indices. This showed that plots $\mathrm{A}$ and $\mathrm{B}$ were the most similar in terms of mushroom assemblage, while plots $\mathrm{B}$ and $\mathrm{D}$ were the most dissimilar (Table 4). Furthermore, plots $\mathrm{C}$ and $\mathrm{D}$ also recorded high similarity index values. This is reflected in the Chao shared estimate and the number of observed shared macrofungal species recorded between plots A and B (23), and C and D (18), respectively.

\section{Phenology}

Phenology, i.e. the time-scale between fruit body appearance and disappearance, was monitored monthly and $30.7 \%$ of the total species encountered during the study produced fruit bodies that appeared and disappeared within a month. The phenological pattern of fruit bodies were observed to vary across species, sampled plots and mushroom forms. The macrofungi with the longest fruiting season (of over 12 months) include A. auricula, Coltricia perennis (L.) Murr., D. concentrica, Nothopanus sp., $P$. squarrosulus and $S$. commune. Macrofungi with shorter (compressed) or latent fruiting seasons ranging between 1-28 days were mostly members of the family Agaricaceae and include Helotium citrinum (Hedwig.) Fr., Leccinum sp., Omphalina chrysophylla (Fr.) Murr., Tarzetta rosea (Rea.) Dennis, Podoscypha sp. (Table 1). The rainy months of May-Oct marked the peak of fruit body appearance or phenological activity and almost $65 \%$ of all fruibodies were observed during this period. Fructification, however, dipped in the dry months with the appearance of Calvatia cyathiformis (Bosc.) Morg., Daedalea quercina Fr., Pycnoporus sanguineus (L.) Murr., Trametes sp. and Xylaria species. Mushrooms with ephemeral fruit bodies were observed to be mostly litter colonizers.

\section{Abundance, climate factor and littermass}

The monthly abundance dataset was compared with monthly climate perturbations. The monthly mushroom abundance distribution was found to correlate with rainfall, temperature, relative humidity and wind-speed (Fig. 3a, $3 b)$. The monthly littermass distribution profile, on the other hand, was inversely related to the abundance and rainfall pattern throughout the study. Plots A and B, though recording the least diversity and species richness index values, still showed the highest total (annual) littermass: $459 \mathrm{~g} \mathrm{~m}^{-2}$ and $284 \mathrm{~g} \mathrm{~m}^{-2}$, respectively (Table 2).

\section{Discussion}

The rubber agroforest systems selected for this study yielded a total of 76 macrofungal species over a combined land area of $1000 \mathrm{~m}^{2}$, a total of 333 fruit bodies (abundance) which translates to 4.38 fruit bodies per species, month and sampling effort. This value, according to Gotelli and Colwell (2001) arithmetically increases with sampling (survey) intensity, size of sample area and number of samplers. The abundance-sample based accumulation curve (Fig. 2) according to Colwell et al. (2004) measured the number of observed species as a function of sampling effort using the abundance distribution dataset and EstimateS statistical software package. This showed no asymptote reflecting the incompleteness of extant mushroom census and/or taxa covered by this study. Thus, many more macrofungal species that are highly specialised in function, ephemeral, lichenized and hypogeous and/or exhibited latent fructification may have escaped observation during this study and remained cryptic. Therefore, further 
Table 1. Diversity of macrofungi, their phenology, substrate propensity and sociability. ${ }^{* * * *}{ }^{*}$ Class, ${ }^{* * *}$ order, ${ }^{* *}$ group, $*$ family, $+=$ present, $-=$ absent, $\mathrm{AYR}=$ all year round, $\mathrm{BW}=$ buried wood, $\mathrm{DL}=$ decomposing litter, $\mathrm{DW}=$ dead decaying wood (tree stump and fallen logs), $\mathrm{S}=$ soil, $\mathrm{T} / \mathrm{TB}=$ living tree

\begin{tabular}{|c|c|c|c|c|c|c|c|}
\hline \multirow[t]{2}{*}{ Species } & \multicolumn{4}{|c|}{ Sample plot } & \multirow[t]{2}{*}{ Phenology } & \multirow[t]{2}{*}{ Substrate } & \multirow[t]{2}{*}{ Total abundance } \\
\hline & A & $\mathrm{B}$ & $\mathrm{C}$ & $\mathrm{D}$ & & & \\
\hline $\begin{array}{l}\text { ASCOMYCOTINA } \\
* * * * \text { DISCOMYCETES } \\
* * * \text { HELOTIALES } \\
* \text { LEOTIACEAE }\end{array}$ & & & & & & & \\
\hline $\begin{array}{l}\text { Helotium citrinum (Hedwig.) Fr. } \\
\text { ***PEZIZALES } \\
\text { *PYRONEMATACEAE }\end{array}$ & - & + & - & - & Sep & DW & 2 \\
\hline Tarzetta rosea (Rea.) Dennis. & + & + & - & + & Sep & DW & 6 \\
\hline $\begin{array}{l}\text { *SARCOSCYPHACEAE } \\
\text { Cookeina sulcipes (Berk.) Kunt. } \\
\text { ****PYRENOMYCETES } \\
\text { ***SPHAERIALES } \\
\text { *XYLARIACEAE }\end{array}$ & + & + & - & - & Jul-Nov & DW & 7 \\
\hline $\begin{array}{l}\text { Daldinia concentrica (Bolt. ex Fr) Ces. and DeNot } \\
\text { Xylaria sp. } \\
\text { X. hypoxylon (L. ex Hook) Grev. } \\
\text { X. polymorpha (Pers. ex Mér.) Grev. }\end{array}$ & $\begin{array}{l}+ \\
- \\
- \\
-\end{array}$ & $\begin{array}{l}+ \\
- \\
- \\
-\end{array}$ & $\begin{array}{l}+ \\
- \\
+ \\
+\end{array}$ & $\begin{array}{l}+ \\
+ \\
- \\
+\end{array}$ & $\begin{array}{l}\text { AYR } \\
\text { Sep-Feb } \\
\text { Sep-Apr } \\
\text { Jan-Dec }\end{array}$ & $\begin{array}{l}\text { DW } \\
\text { DW } \\
\text { DW } \\
\text { DW }\end{array}$ & $\begin{array}{r}19 \\
2 \\
5 \\
3\end{array}$ \\
\hline $\begin{array}{l}\text { BASIDIOMYCOTINA } \\
* * * * \text { HYMENOMYCETES } \\
\text { ***AGARICALES } \\
\text { **AGARIC FUNGI } \\
\text { *AGARICACEAE }\end{array}$ & & & & & & & \\
\hline Agaricus arvensis Schaeff. & + & - & - & - & Jun & $\mathrm{DL}$ & 3 \\
\hline $\begin{array}{l}\text { *AMANITACEAE } \\
\text { Amanita phylloides (Vail.) Secr. }\end{array}$ & - & - & - & + & Jan, Aug & DW & 1 \\
\hline $\begin{array}{l}\text { *BOLETACEAE } \\
\text { Leccinum sp. }\end{array}$ & - & + & - & - & Sep & $\mathrm{DL}, \mathrm{S}$ & 2 \\
\hline $\begin{array}{l}\text { *COPRINACEAE } \\
\text { Copinus acuminatus (Romagn.) Orton } \\
\text { Coprinus atramentarius Ulje and Bas. } \\
\text { Coprinus disseminatus (Pers. ex Fr.) S. F. G. } \\
\text { Omphalina chrysophylla (Fr.) Murr. } \\
\text { Panaeolus foenisecii (Pers: Fr) Kuhn. }\end{array}$ & $\begin{array}{l}+ \\
+ \\
+ \\
- \\
+\end{array}$ & $\begin{array}{l}+ \\
+ \\
+ \\
- \\
+\end{array}$ & $\begin{array}{l}+ \\
- \\
- \\
+ \\
-\end{array}$ & $\begin{array}{l}+ \\
- \\
- \\
+ \\
-\end{array}$ & $\begin{array}{l}\text { Jun-Aug } \\
\text { Jul-Sep } \\
\text { Jul-Sep } \\
\text { Sep } \\
\text { Jun-Sep }\end{array}$ & $\begin{array}{l}\text { DL } \\
\text { DL, DW } \\
\text { DL } \\
\text { DW } \\
\text { DW }\end{array}$ & $\begin{array}{r}20 \\
7 \\
2 \\
6 \\
7\end{array}$ \\
\hline $\begin{array}{l}\text { *CREPIDOTACEAE } \\
\text { Crepidotus mollis (Bull.) Kum. }\end{array}$ & + & + & + & - & Aug-Nov & DW & 4 \\
\hline $\begin{array}{l}\text { *HYGROPHORACEAE } \\
\text { Hygrocybe sp. } \\
\text { H. cantharellus (Schw.) Murr. } \\
\text { *PLEUROTACEAE }\end{array}$ & $\begin{array}{l}- \\
+\end{array}$ & $\begin{array}{l}- \\
+\end{array}$ & $\begin{array}{l}- \\
-\end{array}$ & $\begin{array}{l}+ \\
-\end{array}$ & $\begin{array}{l}\text { Jul-Sep } \\
\text { Jun-Aug }\end{array}$ & $\begin{array}{l}\mathrm{DL}, \mathrm{S} \\
\mathrm{DL}\end{array}$ & $\begin{array}{l}1 \\
4\end{array}$ \\
\hline $\begin{array}{l}\text { Nothopanus sp. } \\
\text { Pleurotus sp. } \\
\text { P. squarrosulus (Fr.) Kum. } \\
\text { P. tuberregium (Fr.) Singer }\end{array}$ & $\begin{array}{l}+ \\
- \\
+ \\
-\end{array}$ & $\begin{array}{l}+ \\
- \\
+ \\
-\end{array}$ & $\begin{array}{l}+ \\
+ \\
+ \\
+\end{array}$ & $\begin{array}{l}+ \\
+ \\
+ \\
+\end{array}$ & $\begin{array}{l}\text { AYR } \\
\text { Jun-Sep } \\
\text { AYR } \\
\text { Jul }\end{array}$ & $\begin{array}{l}\text { DW } \\
\text { DW, S } \\
\text { DW } \\
\text { DW, S }\end{array}$ & $\begin{array}{r}11 \\
2 \\
7 \\
1\end{array}$ \\
\hline $\begin{array}{l}\text { *PLUTACEAE } \\
\text { Pluteus cervinus (Schaeff. ex Fr.) Kum. } \\
\text { *TRICHOLOMATACEAE }\end{array}$ & - & - & + & - & Aug & DW & 5 \\
\hline $\begin{array}{l}\text { Clitocybe sp. } \\
\text { C. dealbata (Sow.) Gillet. } \\
\text { Maramius lachnophyllus Berk. } \\
\text { M. rotula (Fr.) Scope } \\
\text { Marasmiellus sp. } \\
\text { Megacollybia platyphylla (Pers.) kotl. and Pouzar. } \\
\text { Mycena pearsoniana (Cooke) Sacc. } \\
\text { Panellus sp. } \\
\text { Pleurocybella porrigens (Pers. ex Fr.) Sing. }\end{array}$ & $\begin{array}{l}+ \\
+ \\
+ \\
+ \\
+ \\
- \\
+ \\
+ \\
-\end{array}$ & $\begin{array}{l}+ \\
+ \\
- \\
+ \\
+ \\
- \\
+ \\
+ \\
-\end{array}$ & $\begin{array}{l}- \\
+ \\
- \\
- \\
- \\
- \\
- \\
+ \\
+\end{array}$ & $\begin{array}{l}- \\
- \\
- \\
- \\
- \\
+ \\
- \\
- \\
+\end{array}$ & $\begin{array}{l}\text { Jun-Jul } \\
\text { Jun-Sep } \\
\text { Jul-Aug } \\
\text { Jun-Sep } \\
\text { Aug-Sep } \\
\text { Aug-Sep } \\
\text { Jul-Aug } \\
\text { Sep } \\
\text { Aug-Sep }\end{array}$ & $\begin{array}{l}\mathrm{DL} \\
\mathrm{DL} \\
\mathrm{DL} \\
\mathrm{DL} \\
\mathrm{DW} \\
\mathrm{DW} \\
\mathrm{DL} \\
\mathrm{DW} \\
\mathrm{DW}\end{array}$ & $\begin{array}{l}5 \\
7 \\
2 \\
9 \\
2 \\
4 \\
4 \\
5 \\
4\end{array}$ \\
\hline $\begin{array}{l}\text { ***APHYLLOPHORALES } \\
\text { **POLYPORE } \\
\text { *AURICULARIACEAE }\end{array}$ & & & & & & & \\
\hline $\begin{array}{l}\text { Auricularia auricula Judae (Bull.) Pat. } \\
\text { *CLAVARIACEAE }\end{array}$ & + & + & + & + & AYR & DW & 18 \\
\hline $\begin{array}{l}\text { Clavulina sp. } \\
\text { Thelephora sp. A } \\
\text { Thelephora sp. B }\end{array}$ & $\begin{array}{l}- \\
- \\
-\end{array}$ & $\begin{array}{l}- \\
- \\
-\end{array}$ & $\begin{array}{l}- \\
+ \\
+\end{array}$ & $\begin{array}{l}+ \\
- \\
+\end{array}$ & $\begin{array}{l}\text { Sep } \\
\text { Sep } \\
\text { Oct-Nov }\end{array}$ & $\begin{array}{l}\text { DW } \\
\text { DW } \\
\text { DW }\end{array}$ & $\begin{array}{l}2 \\
4 \\
6\end{array}$ \\
\hline
\end{tabular}


Species

A $\quad$ B $\quad$ C $\quad$ D

*HYDNACEAE

Hericium ramosum (Bull. ex Mèr.) Let.

*HYMENOCHAETACEAE

Coltricia perennis (L.: Fr.) Murr.

Inonotus cuticularis (Bull.) Kar.

*PODOSCYPHACEAE

Podoscypha sp.

*POLYPORACEAE

Bondarzewia sp.

Daedaelia quercina Fr.

Fomes fomentarius (Fr.) Kickx.

Ganoderma applanatum (Pers. ex Wall.) Pat.

G. lucidum (Leyss.) P, Kar.

G. tsugae Murrill

Pycnoporus cinnabarinus (Fr.) Kar.

Trametes sp.

*SCHIZOPHYLLACEAE

Schizophyllum commune Fr.

*STEREACEAE

Stereum purpureum (Pers ex Fr.) Fr.

***DACRYMYCETALES

*DACRYMYCETACEAE

Calocera cornea (Batsch.) Fr.

***TREMELLALES

*TREMALLACEAE

Exidia thurentiana (Lev.) Fr.

Tremella sp.

T. fuciformis Berk.

****GASTEROMYCETES

***LYCOPERDALES

**STOMACH FUNGI

*LYCOPERDACEAE

Calvatia cyathiformis (Bosc.) Morg.

***NIDULARIALES

*NIDULARIACEAE

Cyathus striatus (Huds.) Willd.

**UNIDENTIFIED

RRIN04

RRIN05

RRIN06

RRIN07

RRIN08

RRIN09

RRIN11

RRIN13

RRIN14

RRIN15

RRIN17

RRIN20

RRIN21

RRIN22

RRIN23

RRIN24

RRIN25

RRIN26

RRIN27

RRIN28

Total

\begin{tabular}{|c|c|c|c|c|c|}
\hline+ & + & - & - & Sep-Oct & DW \\
\hline+ & + & - & - & AYR & DW \\
\hline- & - & + & + & Jul-Aug & DW \\
\hline- & - & + & - & Jun & DW \\
\hline- & - & - & + & Aug & DW \\
\hline - & - & - & + & Nov & DW \\
\hline- & - & - & + & Jan-Mar & $\mathrm{DW}, \mathrm{T}$ \\
\hline - & + & - & + & Sep-Jan & $\mathrm{DW}, \mathrm{DL}$ \\
\hline- & - & + & + & Aug & DW \\
\hline - & + & + & - & Jul-Dec & $\mathrm{DW}, \mathrm{T}$ \\
\hline- & + & - & - & Jan & DW \\
\hline- & - & - & + & Jan & DW \\
\hline+ & + & + & + & AYR & DW \\
\hline- & - & - & + & Dec-Mar & DW \\
\hline - & + & - & - & Jul & DW \\
\hline 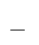 & - & - & + & Aug-Sep & DW \\
\hline+ & - & - & - & Sep-Dec & DW \\
\hline & - & + & + & Sep-Dec & DW \\
\hline
\end{tabular}

\begin{tabular}{|c|c|c|c|c|c|}
\hline - & - & - & + & Jan-Feb & DL \\
\hline+ & + & + & + & Sep-Jan & DW \\
\hline - & + & - & - & Sep & DW \\
\hline- & + & - & - & Mar & DW \\
\hline - & - & - & + & Jul-Aug & DW, TB \\
\hline+ & + & - & - & Sep-Nov & DW \\
\hline+ & - & - & - & Mar & DW \\
\hline+ & + & - & - & Jul-Aug & DL \\
\hline+ & + & - & - & Jul-Sep & $\mathrm{DL}$ \\
\hline - & - & + & - & Apr-Mar & DW \\
\hline - & - & + & - & Mar-Oct & DW \\
\hline - & - & + & - & Mar-Oct & DW \\
\hline+ & + & - & - & Jan & DW \\
\hline+ & - & - & - & Jul-Aug & DW \\
\hline+ & - & - & + & Feb & DW \\
\hline - & - & + & + & Mar-Sep & $\mathrm{BW}, \mathrm{DL}$ \\
\hline - & - & - & + & Mar & $\mathrm{DL}$ \\
\hline+ & - & - & - & Aug & $\mathrm{DL}$ \\
\hline- & - & - & + & Jun-Aug & DW \\
\hline - & - & + & + & Jul. & DW \\
\hline+ & + & - & - & Aug-Sep & $\mathrm{DL}$ \\
\hline - & - & - & + & Jan-Feb & DW \\
\hline
\end{tabular}

long-term studies are required to achieve a more robust and exhaustive inventory of macrofungi taxa in the study area and understand the role of the functional group diversity of mushrooms on the productivity level of agroecosystems.
Ecodiversity and census of macrofungi in forest systems are substantially more venerable in the literature compared to agroecosystems (Lodge et al. 1995, Straatsma et al. 2001, Straatsma and Krisai-Greilhuber 2003). This was reported based on the concept that forests entrenched a more 
Table 2. Summary of mushroom species parameters and total annual littermass $\left(\mathrm{g} \mathrm{m}^{-2}\right)$ per plot. Values in parenthesis represent number of unshared species that remained unidentified.

\begin{tabular}{|c|c|c|c|c|c|}
\hline Sample plot & Total no. of sp. & No. of unidentified sp. & No. of unshared sp. & No. of fruit body & Total litter mass $\left(\mathrm{g} \mathrm{m}^{-2}\right)$ \\
\hline A & 34 & 9 & $6(3)$ & 83 & 458.7 \\
\hline B & 35 & 7 & $5(2)$ & 88 & 283.9 \\
\hline C & 29 & 5 & $7(3)$ & 83 & 179.5 \\
\hline D & 37 & 7 & $12(4)$ & 79 & 235.9 \\
\hline
\end{tabular}

balanced, naturally diverse heterobiotic community, in addition to representing a large pool of the global carbonbudget (Hawksworth 1991, Lodge et al. 1995, Straatsma et al. 2001, Straatsma and Krisai-Greilhuber 2003, Mueller et al. 2007). Out of the 76 mushroom species recorded during theis study, 56 were named and classified. These belonged to 25 different macrofungal families within the Ascomycetes and Basidiomycetes, with the latter having $87.5 \%$ of the mushroom taxa (Table 1). The quantity of mushrooms recorded within the short period of study compares relatively well with other mushroom diversity studies in tree-dominated tropical ecosystems (Shigeki et al. 1994, Dijk et al. 2003, Schmit 2005, Lynch and Thorn 2006) and showing that homogeneous woodlands (agroforests) are comparable to natural forests with respect to mushroom abundance (Chiarucci et al. 2005). Suffice to say that agroecosystems, especially rubber plantations, are depauperate alternative mushroom pools in Nigeria and beyond (Osemwegie et al. 2006, Osemwegie and Okhuoya 2009).

The dominance of saprotrophic basidiomycetous mushroom taxa recorded during the study may be connected to the preponderance of carbon-based wood substrates (Hawksworth 2001, Chiarucci et al. 2005). This, according to Lindblad (2001) and Weedon et al. (2009), controls the distribution of macrofungi and their habitat. The data on the substrate distribution in the study area showed that woodbased substrates harboured $66 \%$ of the total number of taxa recorded, while decomposing litters supported $19 \%$. This observation is in accordance with the high number of Basidiomycetes recorded during the study, and may be attributed largely to the varied level of high-energy carbon compounds and lignocellulose content of woods and/or the enzyme-substrate dynamics of saprotrophic mushrooms. Little is currently known about the utilization mechanism of wood-based organic resources by mushrooms and the role of resource quality (chemical and structural nature) in structuring the diversity of macrofungal assemblages in Nigerian agroforest and forest systems. The wide spectrum of specialized biodegrading enzymes may have equally accounted for the $15 \%$ of facultative substrate colonizers

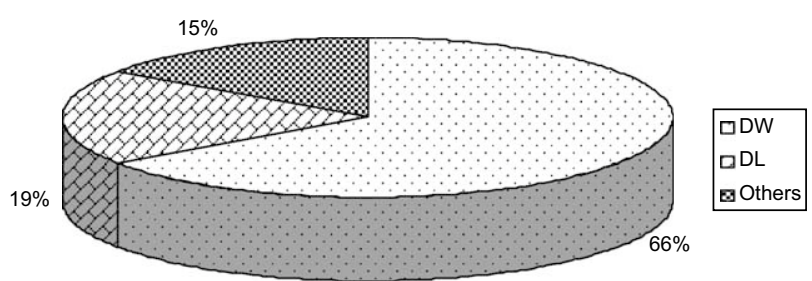

Figure 1. Distribution of mushroom fruit bodies amongst substrates. $\mathrm{DL}=$ decomposing litter, $\mathrm{DW}=$ dead decaying wood. (mushrooms capable of colonizing two substrates differing in both chemical and morphological quality).

The abundance-distribution pattern showed that plot B (whith 32 species) had a high abundance value of 88 , while plot $\mathrm{D}$ (with the highest number of species, 37) had the lowest abundance of 79 (Table 2). The use of the EstimateS statistical software package for the estimation of the number of individuals per sampled plot minimises bias due to differences in sampling intensity and frequency, and revealed a strong correlation between abundance and number of individuals (Table 3). Mushroom biodiversity works on woodland ecosystems involving the application of EstimateS in data analysis are scarce and this study, therefore, represents a baseline reference for future studies. The differences in abundance datasets between sampled plots correlates positively with species richness (Bootstrap, Chao 1, Jackknife) and diversity indices (Alpha, Simpson) of macrofungi recorded by the study. This also revealed an interesting diversity and richness pattern along the plantation age gradient, in which plot $\mathrm{A}$ had the lowest species diversity and plot $\mathrm{D}$ the highest. The long-term effects of redundancy due to reduced level of human activities, vegetation structure (tree compactness, fragmentation, gap and edge effect), and characteristics (level of under-storey growth, tree size and girth, canopy structure, physiognomy, litterfall dynamics, detritus activities etc.) may have been responsible for this trend. Giller and O'Donovan (2002) remarked that the intrinsic ecological balance in many vegetation types seldom disturbed by humans, with a natural level of heterogeneity and structural integrity exert strong control on mycodiversity and mushroom community structure. The age of a forest or agroforest systems obviously determines its ecological structure, intrinsic characteristics, the holistic content of species representativeness and/or endemism, habitat diversity and the level of diversity of the inhabiting biological communities. Consequently, the age of a vegetation in this context is a measure of latitudinal space or time scale that drives the temporal and spatial processes of ecological evolution, biological succession and natural selection. It may therefore also be responsible for the observed level of diversity and species richness in the current study. In addition, the variation range and rate of natural selection in woodland ecosystems greatly impact species abundance, diversity, richness and composition (assemblage) of mushrooms, both locally and globally (Hawksworth 2001, Chiarucci et al. 2005). Lodge et al. (1995) remarked that fungal diversity strongly correlates with habitat, host diversity and resource abundance, driven by age. Understanding the relationships between biodiversity, ecosystem health and functions, in addition to the effect of mushroom community structure, on the productivity of agroforests is vital for 
Table 3. Species richness and diversity indexes \pm SD derived from 100 randomization accumulation order of abundance- sample set data per sampled plot.

\begin{tabular}{lrrrr}
\hline Estimators (mean value) & \multicolumn{3}{c}{ Sampled plot } \\
\cline { 2 - 5 } & \multicolumn{1}{c}{ A } & B & C & D \\
\hline Sobs (Mao Tau) & $32.0 \pm 2.5$ & $52.0 \pm 3.2$ & $66.5 \pm 3.7$ & $76.0 \pm 4.0$ \\
Singletons & $7.28 \pm 2.8$ & $11.13 \pm 4.0$ & $12.54 \pm 3.3$ & $11.0 \pm 0.0$ \\
Doubletons & $10.56 \pm 2.1$ & $15.65 \pm 3.5$ & $18.87 \pm 1.4$ & $21.0 \pm 0.0$ \\
Chao 1 & $34.48 \pm 2.2$ & $56.58 \pm 2.9$ & $70.91 \pm 3.0$ & $78.5 \pm 2.3$ \\
Jack 1 & $32.33 \pm 0.0$ & $73.64 \pm 2.0$ & $96.23 \pm 10.0$ & $104.5 \pm 6.5$ \\
Bootstrap & $32.33 \pm 2.8$ & $63.3 \pm 10.4$ & $80.62 \pm 4.5$ & $89.91 \pm 0.0$ \\
Alpha & $19.99 \pm 3.6$ & $27.42 \pm 3.4$ & $30.05 \pm 3.0$ & $30.66 \pm 2.7$ \\
Simpson & $37.7 \pm 6.6$ & $46.6 \pm 7.8$ & $47.83 \pm 3.5$ & $49.33 \pm 0.0$ \\
\hline
\end{tabular}

healthy conservation planning and improved agroforest management practices in Nigeria.

The number of rare or unseen (cryptic) species reflected by the Singleton estimator showed that plot $\mathrm{C}$ had the highest Singleton value which, however, was only marginally different from those of plot B and D, while plot A had the lowest value (Table 3). The differences in Singleton values across sampled plots may be due to lapses in sampling efforts and/or time (Table 3).

The estimation of species similarities (Bray-Curtis, Jaccard, Morisita-Horn and Sørensen indices) between the surveyed rubber plots showed that plots A and B were the most similar in species composition and number of unshared species, while plots $\mathrm{B}$ and $\mathrm{D}$ were the most dissimilar. The values of similarity estimators computed from the data sets showed a compositional similarity or dissimilarity (distinctiveness) across the age gradient. Compositional dissimilarity in species assemblage, as found especially between plots A and D, and plots B and D, may be due to a concatenation of factors i.e. scale of environmental heterogeneity (Laitung and Chauvet 2005), distance between sampled sites and/or varied spatial patterns of spore dispersal (Chao et al. 2005). According to Chao et al. (2005), the level of species rarity (Singleton) can undermine the values of recorded similarity indices. This is because only the exhaustive capture of mushrooms in the surveyed

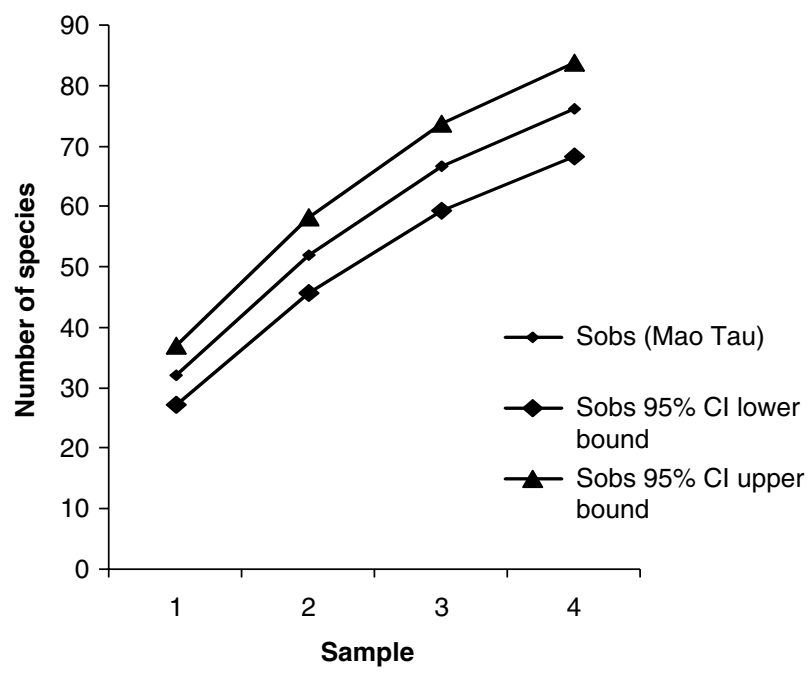

Figure 2. Species-sample based accumulation curve of the study area. plots can remove the false sense of rarity and reveal the true ecological comparison of shared species.

Straatsma et al. (2001) and Straatsma and Krisai-Greilhuber (2003) extolled the significance of visible fruit body occurrence over mycelium in macrofungal studies while Lodge et al. (2004) described it as representing the reproductive part of a fungus. This is used interchangeably with mushrooms in interpreting phenological behaviours observed during this study. A. auricular, C. perennis, D. concentrica, Nothopanus sp., P. squarrosulus and $S$. commune produced fruit bodies that remained visible and gregarious throughout the period of the study. Okhuoya and Akpaja (2005) reported that many of these aforementioned mushrooms impacted socio-culturally on the livelihood of the suburban people of Edo State as sustainable sources of income, food and folkmedicine. This therefore raised the question of whether there is a link between phenology, which within this context may be interchanged with availability of mushrooms, their sociocultural uses and a gregarious growth pattern (gregariousness). These mushroom taxa also interestingly belonged to the same functional group (species performing similar ecological functions) of wood degraders (Grime 1997). Although further studies are required to answer this question, field observations during the study, which was in accordance with Osemwegie and Okhuoya (2009), inclined towards a correlation between mushroom phenological pattern, growth habit (caespitose or gregarious) and their socio-cultural uses. This is also obvious from the abundance values recorded for each mushroom species (Table 1).

The resilience of mushrooms to meteorological perturbations (range of environmental tolerance, season-overlap), their intraspecific growth behaviour or gregariousness and efficient resource utilization traits have been observed to be a natural evolutionary invention for genetic adaptation (Gregory 1984, Ohga et al. 2000). The short (ephemeral) phenological patterns or compressed fruiting season (1-28 days) displayed by $H$. citrinum, Leccinum sp., O. chrysophylla, T. rosea and Podoscypha sp., most of which belong to the family Agaricaceae, may be innate (genetic). Furthermore, factors such as the functional role of the species and spore dissemination expressed by some mushrooms, and systematic fungivory by many invertebrates and vertebrates may also negatively affect the longevity or appearance of fruit bodies in the field (Guevara and Dirzo 1999, Kauserud et al. 2008, Meier and Bowman 2008). Fruit body production and abundance were observed to peak during the rainy season (May-Oct) and dipped in the dry season, when only droughttolerant species such as $C$. cyathiformis, $D$. quercina, 
Table 4. Matrix of similarity indexes between sampled plots.

\begin{tabular}{lccccccc}
\hline First sample & $\begin{array}{c}\text { Second } \\
\text { sample }\end{array}$ & $\begin{array}{c}\text { Shared species } \\
\text { observed }\end{array}$ & $\begin{array}{c}\text { Chao shared } \\
\text { estimated }\end{array}$ & $\begin{array}{c}\text { Jaccard } \\
\text { classic }\end{array}$ & $\begin{array}{c}\text { Sorensen } \\
\text { classic }\end{array}$ & Morisita-Horn & Bray-Curtis \\
\hline A & B & 23 & 24.653 & 0.575 & 0.73 & 0.826 & 0.702 \\
A & C & 8 & 8.952 & 0.154 & 0.267 & 0.331 & 0.249 \\
A & D & 7 & 7.323 & 0.117 & 0.209 & 0.281 & 0.211 \\
B & C & 9 & 10.2 & 0.173 & 0.295 & 0.358 & 0.276 \\
B & D & 7 & 7.00 & 0.115 & 0.206 & 0.311 & 0.217 \\
C & D & 18 & 20.438 & 0.383 & 0.554 & 0.549 & 0.463 \\
\hline
\end{tabular}

$P$. cinnabarinus, Trametes sp. and $X$. polymorpha were recorded. This is in agreement with the findings of Straatsma et al. (2001), Munguia et al. (2006) and Kauserud et al. (2008). Species abundance recorded from the study showed a stronger correlation with precipitation (rainfall) than with temperature, wind-speed and relative humidity. This result also agreed with Lodge et al. (1995) and Osemwegie and Okhuoya (2009). In addition, it proves the indispensable role of local climate, especially rainfall, in structuring mushroom community and diversity through a complex network of regulatory, stimulatory and inductive mechanisms that drive fructification (Fig. 3). Although, the method and scope of this study provided little understanding of the influence of climate variables, individually or collectively, on the different mushroom taxa or their ecological status, it showed that the combined effect of climate variables is more influential in determining macrofungal diversity and phenology than the action of any one single variable. The spatial and temporal extent to which each climate variable influences mushroom fructification and phenology in natural, semi-natural and human-made vegetation are poorly understood and will require more research to understand the ecophysiological pathways and biochemical dynamics. Future research should take into account the works of Braga-Neto et al. (2007) and Osono (2007) who proposed a strong relationship between the absorptive nutrition character of saprotrophic mushrooms and substrate-moisture dynamics.

On the contrary, the monthly littermass profile for each sampled plot was inversely related to both the rainfall pattern and the abundance of fruitbodies. Further studies are, however, required to prove and underpin the level of the triangular relationship between ambient climate, mushroom abundance and littermass of rubber agroforest and forest systems. Plot A had the lowest species richness and diversity, but recorded the highest littermass value $458.7 \pm 15.1 \mathrm{~g} \mathrm{~m}^{-2}$. Plot $\mathrm{D}$, on the other hand, had the (a)

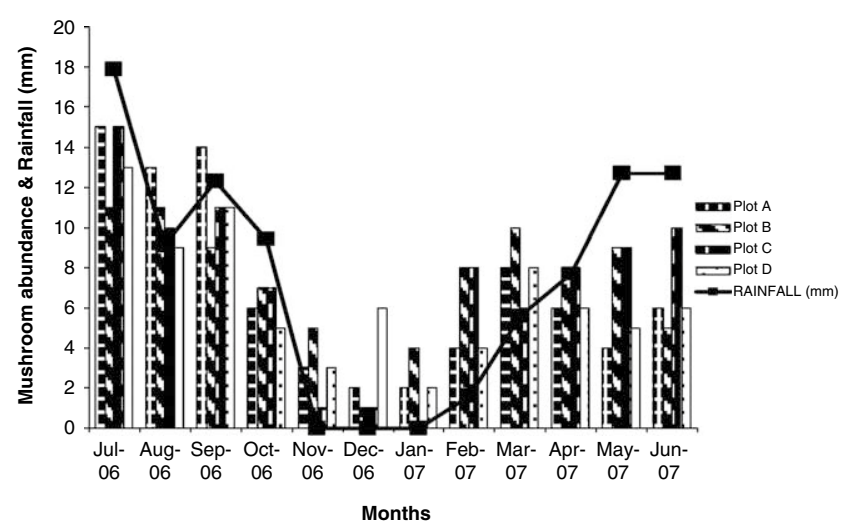

(c)

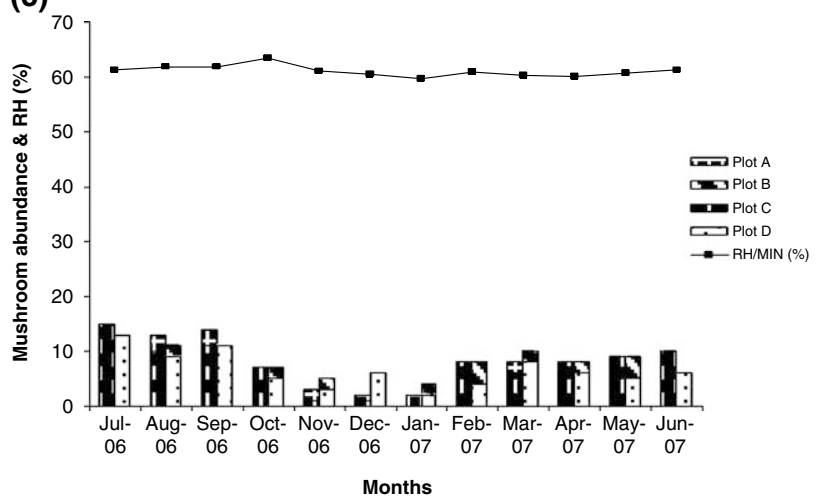

(b)
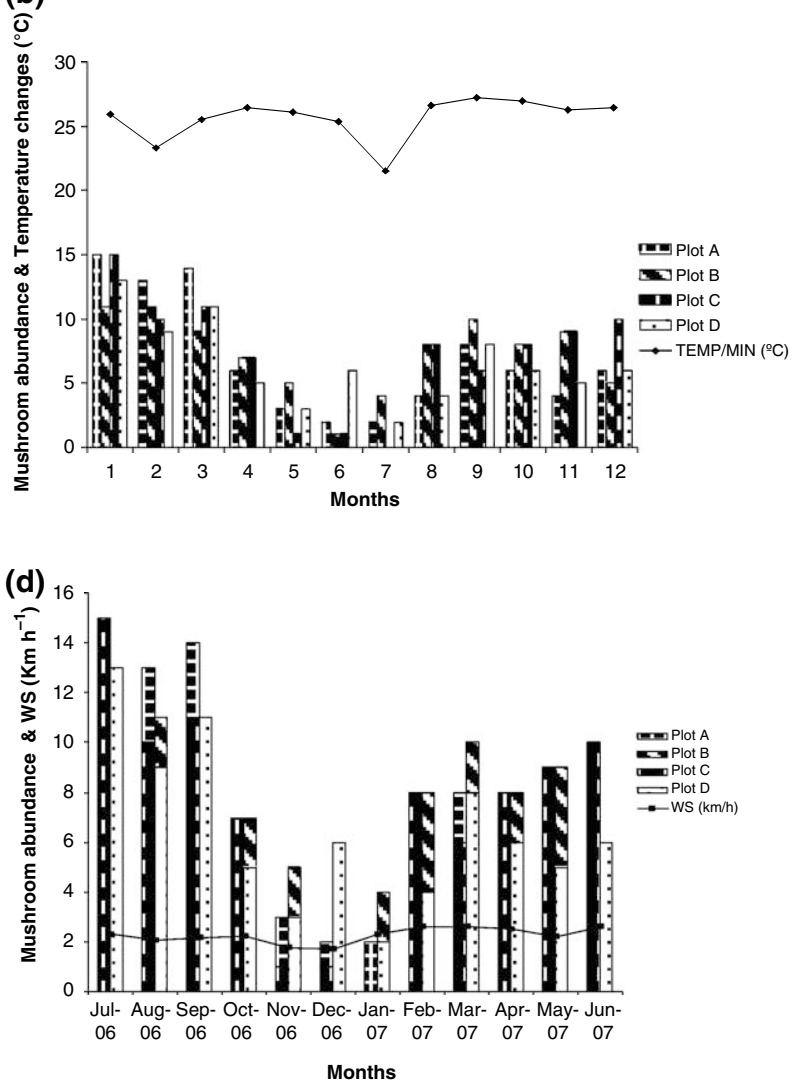

Figure 3. (a) comparative profile of mushroom abundance (MA) and climate variables per plot, (b) comparative profile of monthly climate variables and littermass (LM) per plot. 
lowest value of $235.9 \pm 10.6 \mathrm{~g} \mathrm{~m}^{-2}$, despite having the highest species number and diversity indices. The low macrofungal diversity and species richness estimators recorded for plot A may be attributed to the effect of anthropogenic pressure on/and the structure of the system. Furthermore, the obvious anti-parallel relationship observed between rainfall and littermass, and the heavy incidence of litterfall in sampled plots with low mushroom diversity and species richness values, can be attributed to the deciduous nature of rubber trees, whose leaf abscission dynamics may be tied to the age of the plantation and coincided with the dry season. The ratios of leaflitter to wood debris, both of which constituted the littermass, exerts a strong influence on resource and/or substrate distribution in forest and agroforest systems. This would consequently impact on the macrofungal community of the study area due to variations in resource utilization and selectivity (Tilman et al. 1997, Braga-Neto et al. 2007, Weedon et al. 2009). In addition, resource utilization, selectivity and distribution may be more cardinal to the functional group diversity and composition structure of mushrooms in woodland ecosystems than their species richness and diversity (Grime 1997). This may have accounted for the best representation of the family Tricholomataceae recorded during the study, most of which are litter decomposers with compressed to ephemeral phenology (Osono 2007).

This study proves that rubber agroforests are a potentially sustainable alternative pool of utilitarian macrofungi and suggests a strong positive correlation between macrofungal abundance, species richness diversity, climate variables and vegetation age. It also acknowledged that the role of climate and litter variables on macrofungal diversity, composition and community structure is fundamental to the conceptualization of sustainability, stability and productivity of rubber agroforests. The number of macrofungi revealed during this study challenges the exclusion of agroforests from the lists of viable vegetations meta-analysed for extrapolating a global fungi estimate (May 1991, Hawksworth 2001, Hawksworth and Mueller 2005, Mueller et al. 2007, Schmit and Mueller 2007). Although the concerted effects of climate variables exerted stronger control on macrofungal diversity and species richness in rubber agroforests than any single individual physical factor, precipitation still stood out as the inertia of multitrophic decomposition processes and mushroom fructifications. The natural, but differing sensitivity of mushrooms to climate variables (selected or general) as established by this study, qualifies mushrooms as good bioindicators and/or biomonitors of climate change. This study further acknowledges wood-based substrates and their distribution as more cardinal in describing mushroom abundance, diversity and species richness compared to leaf-litters. This study serves as a basic reference for future ecodiversity studies of macrofungi in agroforests both in Nigeria and other west African subregions.

Acknowledgements - Gratitude to the Univ. of Benin management for partly funding the research and the management of Rubber Research Inst. of Nigeria for approving the use of their plantations, surrounding forests and the plant protection laboratory for the research in addition to providing meteorological information required during the period of study. The authors also appreciate the contributions of Dr S. O. Isikhuemhen from Mushroom Biology and Fungal Biotechnology Lab, School of Agriculture and Environmental Sciences, North Carolina, Agriculture and Technical State Univ. and Dr Cathie M Aime from the Dept of Plant Pathology and Crop Physiology, Louisiana State University Agricultural Center for their advice and training during their visit to the Mushroom Biology Unit of the Univ. of Benin.

\section{References}

Arora, D. 1991. All that the rain promises and more. - Biosystem Analysis Inc. Santa Cruz, California.

Braga-Neto, R. et al. 2007. Leaf litter fungi in a central Amazonian forest: the influence of rainfall, soil and topography on distribution of fruiting bodies. - Biodiv. Conserv. doi 10.1007/s10531-007-9247-6.

Chao, A. et al. 2005. A new statistical approach for assessing compositional similarity based on incidence and abundance data. - Ecol. Lett. 8: 148-159.

Chiarucci, A. et al. 2005. Using vascular plants as a surrogate taxon to maximize fungal species richness in reserve design. - Conserv. Biol. 19: 1644-1652.

Colwell, R. K. 2005. EstimateS: statistical estimation of species richness and shared species from samples, ver. 8.0. $-<$ http:// purl.oclc.org/estimates $>$.

Colwell, R. K and Coddinton, J. A. 1994. Estimating terrestrial biodiversity through extrapolation. - Philos. Trans. R. Soc. Lond. Ser. B 345: 101-118.

Colwell, R. K. et al. 2004. Interpolating, extrapolating, and comparing incidence-based species accumulation curves. - Ecology 85: 2717-2727.

Dijk, V. H. et al. 2003. Knowledge and utilization of edible mushrooms by local populations of the rain forest of south Cameroon. - Ambio 32: 19-23.

FAO 2006. Global forest resources assessment 2005: progress towards sustainable forest management. - Food and Agricultural Organization of the United Nations, Rome.

Flynn, B. F. D. et al. 2009. Loss of functional diversity under land use intensification across multiple taxa. - Ecol. Lett. 12: 22-33.

Giller, S. P. and O’Donovan, G. 2002. Biodiversity and ecosystem functions: do species matter? - Biol. Environ. Proc. R. Irish Acad. 102B: 129-139.

Gotelli, J. N. and Colwell, K. R. 2001. Quantifying biodiversity: procedures and pitfalls in the measurement and camparison of species richness. - Ecol. Lett. 4: 379-391.

Gregory, P. H. 1984. The fungal mycelium: a historical perspective. - Trans. British Mycol. Soc. 82: 1-11.

Grime, J. P. 1997. Biodiversity and ecosystem function: the debate deepens. - Science 227: 1260-1261.

Guevara, R. and Dirzo, R. 1999. Consumption of macro-fungi by invertebrates in a Mexican tropical cloud forest: do fruit body characteristics matter? - J. Trop. Ecol. 15: 603-617.

Hawksworth, D. L 1991. The fungal dimension of biodiversity; magnitude, significance and conservation. - Mycol. Res. 95: 641-655.

Hawksworth, D. L. 2001. The magnitude of fungal diversity: the 1.5 million species estimate revisited. - Mycol. Res. 105: $1422-1432$.

Hawksworth, D. L. and Mueller, G. M. 2005. Fungal communities: their diversity and distribution. - In: Dighton, J. et al. (eds), The fungal communities it organization and role in the ecosystem. CRC Taylor and Francis, pp. 27-37.

Jumpponen, A. et al. 2004. Ecological relationships among hypogeous fungi and trees: inferences from association analysis integrated with habitat modelling. - Mycologia 96: 510-525. 
Kauserud, H. et al. 2008. Mushroom fruiting and climate change. - Proc. Natl Acad. Sci. USA 105: 3811-3814.

Laitung, B. and Chauvet, E. 2005. Vegetation diversity increases species richness of leaf-decaying fungal communities in woodland streams. - Arch. Hydrobiol. 144: 473-493.

Largent, D. L. 1986. How to identify mushrooms to genus I: macroscopic features. - Mad River Press. Inc.

Largent, D. L. and Their, D. H. 1984. How to identify mushrooms to genus II: field identification of genera. - Mad River Press.

Lincoff, G. H. 2005. Field guide to mushrooms. - National Audubon Society, New York.

Lindblad, I. 2001. Diversity of poroid and some corticoid woodinhabiting fungi along the rainfall gradient in tropical forests, Costa Rica. - J. Trop. Ecol. 17: 353-369.

Lindner, L. D. et al. 2006. Species diversity of polyporoid and corticioid fungi in northern hardwood forests with differing management histories. - Mycologia 98: 195-217.

Lodge, D. J. et al. 1995. A survey of pattern of diversity in nonlichenized fungi. - Mitteil. Eidgenöss. Forschungsanst. Wald Schnee Landsch. 70: 158-173.

Lodge, D. J. et al. 2004. Collecting and describing macrofungi. - In: Muller, M. G. et al. (eds), Biodiversity of fungi: inventory and monitoring methods. Elsevier Academic Press, pp. $105-197$.

Lynch, J. D. M. and Thorn, G. R. 2006. Diversity of basidiomycetes in Michigan Agricultural soils. - Appl. Environ. Microbiol. 72: 7050-7056.

May, R. M. 1991. - A fondness for fungi. Nature 352: 475-476.

Meier, L. C. and Bowman, D. W. 2008. Links between plant litter chemistry, species diversity and below-ground ecosystem function. - Proc. Natl Acad. Sci. USA 105: 19780-19785.

Mueller, M. G. et al. (eds) (2004). Biodiversity of fungi: inventorying and monitoring methods. - Elsevier Academic Press, pp. 128-168.

Mueller, M. G. et al. 2007. Global diversity and distribution of macrofungi. - Biodiv. Conserv. 16: 37-48.

Munguia, P. et al. 2006. Seasonal community structure of macromycetes in Veracruz, Mexico. - Ecography 29: 57-65.

Ohga, S. et al. 2000. Transciptional regulation of laccase and cellulase in relation to fruit body formation on the mycelium of Lentinula erodes on a sawdust-based substrate. - Mycoscience 41: 149-153.
Okhuoya, J. A. and Akpaja, E. O. 2005. Mycomedicine and ethnomycology: the Nigerian experience. - Int. J. Med. Mushrooms 7: 439-440.

Osemwegie, O. O. and Okhuoya, J. A. 2009. Diversity of macrofungi in oil palm agroforests of Edo State. - J. Biol. Sci. 9: 584-593.

Osemwegie, O. O. et al. 2006. A survey of macrofungi in Edo/Delta region of Nigeria, their morphology and uses. - Glob. J. Pure Appl. Sci. 12: 149-157.

Osemwegie, O. O. et al. 2010. Macrofungi community in rubber plantations and a forest of Edo State, Nigeria. - J. Appl. Sci. 10: 291-298.

Osono, T. 2007. Ecology of ligninolytic fungi association with leaf litter decomposition. - Ecol. Res. 22: 955-974.

Rahman, M. A. 1976. Review of the basement geology of southwestern Nigeria. - In: Kogbe, C. A. (ed.), Geology of Nigeria. Elizabeth Publishing Co., pp. 76-100.

Schmit, P. J. 2005. Species richness of tropical wood-inhabiting macrofungi provides support for species-energy theory. - Mycologia 97: 751-761.

Schmit, P. J. and Mueller, G. M. 2007. An estimate of the lower limit of global fungal diversity. - Biodiv. Conserv. 16: 99-111.

Shigeki, I. et al. 1994. Analysis of mushroom diversity in successional young forests and equilibrium evergreen broadleaved forests. - Mycoscience 35: 1-14.

Straatsma, G. and Krisai-Greilhuber, I. 2003. Assemblage structure, species richness, abundance and distributon of fungal fruit bodies in a seven year plot-based survey near Vienna. - Mycol. Res. 107: 632-640.

Straatsma, G. et al. 2001. Species richness, abundance, and phenology of fungal fruit bodies over 21 years in a Swiss forest plot. - Mycol. Res. 105: 515-523.

Tilman, D. et al. 1997. The influence of functional diversity and composition on ecosystem processes. - Science 277: 1300-1302.

Treu, R. 1998. Macrofungi in oil palm plantations of southeast Asia. - Mycologist 12: 10-14.

Vogt, K. A. et al. 1992. Sporocarp production by Basidiomycetes, with emphasis on forest ecosystems. - In: Carroll, G. C. and Wicklow, D. T. (eds), The fungal community, 2nd ed. Marcel Dekker Inc, pp. 563-581.

Weedon, T. J. et al. 2009. Global meta-analysis of wood decomposition rates: a role for trait variation among tree species? - Ecol. Lett. 12: 45-56. 